\title{
The Democratic Entitlement in an Era of Democratic Recession
}

\author{
Amichai Magen*
}

\begin{abstract}
The global democratic boom, which transformed much of the world's political landscape in the three decades between 1974 and 2004, has also had an indelible impact on international law, most notably in the development of the 'democratic entitlement' claim-namely, that in a world increasingly dominated by democracies there exists an emergent enforceable right to democratic governance in international law. But what would become of the democratic entitlement if the boom turned to bust? The question is no longer hypothetical. For a decade now the momentum of world politics has turned increasingly against democracy's champions. While the dramatic gains of the late twentieth century have not been erased, the global democratic wave hit the shoal somewhere around 1999-2000, plateaued between 2000 and 2005, and has since suffered sustained reversals. This article re-examines the democratic entitlement thesis in light of these recent negative trends in democracy's international fortunes. It argues that the right to democratic governance is a layered, and potentially severable, edifice, parts of which now seem to be eroding, but which is unlikely to be entirely undone by a reverse wave of democratic breakdowns and resurgent authoritarianism. The article then examines some of the main implications of the current democratic recession for the right to democratic governance in international law.
\end{abstract}

\section{Keywords}

Democracy, Governance, Entitlement, Recession, International Law

\section{Introduction}

The global democratic boom, which transformed much of the world's political landscape in the three decades between 1974 and 2004, has also had an indelible impact on international law, particularly in its latter half, following the end of the Cold War. In a 1992

* Senior Lecturer, Lauder School of Government, Diplomacy and Strategy, IDC, Herzliya (Israel); Head of the Governance \& Political Violence Programme, International Institute for Counter-Terrorism, IDC, Herzliya (Israel); Visiting Fellow, Hoover Institution, Stanford University (US). The author wishes to thank Giada Tardivo and Eppi Margolin for their dedicated research assistance; the organisers of the Cambridge Journal of International and Comparative Law Fourth Annual Conference, 'Developing Democracy: Conversations on Democratic Governance in International, European and Comparative Law', where an early version of this article was first presented; and Dr Sarah Nouwen for excellent editorial comments. 
article described variably as 'seminal, 'path-breaking', and 'pioneering,', Thomas Franck asserted that the demise of Soviet communism and the triumph of Western political and economic liberalism put an end to international law's traditional agnosticism regarding forms of domestic governments and paved the way for the emergence of a 'democratic entitlement', meaning an enforceable right to democratic governance in international law. ${ }^{2}$

Franck's thesis unleashed a two-decade torrent of policy and academic debate about the nature of this (alleged) democratic entitlement, its content and scope, and the international legal and institutional consequences flowing from the recognition of such an entitlement. ${ }^{3}$ Disagreements about this or that aspect of the right to democratic governance notwithstanding, the notion of such a right has become deeply entrenched in contemporary international legal thought, borne and undergirded by the global democratic boom. But what would become of the democratic entitlement if the boom turned to bust?

The question is no longer hypothetical. For a decade now the momentum of world politics has turned increasingly against democracy's champions. While the dramatic gains of the late twentieth century have not been erased, the global democratic wave hit the shoal somewhere around 1999-2000, plateaued between 2000 and 2005, and has since suffered sustained reversals. By 2015 the condition of global democratic institutions and procedures declined for nine consecutive years. Indeed, Freedom House observes in its latest 'Freedom in the World' report that 'acceptance of democracy as the world's dominant form of government-and of an international system built on democratic ideas-is under greater threat than at any point in the last 25 years. ${ }^{4}$

This article examines the right to democratic governance in light of recent trends in democracy's international fortunes. It argues that the democratic entitlement is a layered, and potentially severable, construct that may well be eroded but is highly unlikely to be obliterated. The article then explores some of the main implications of the current democratic recession for the right to democratic governance in international law.

1 For a description of the various accolades and impact of Franck's article, see Susan Marks, 'What has become of the Emerging Right to Democratic Governance?' (2011) 22 EJIL 507.

2 Thomas M Franck, 'The Emerging Right to Democratic Governance' (1992) 86 AJIL 46.

3 The accumulated literature pertaining to Franck's thesis is enormous. Leading statements in this field include: Gregory Fox, 'The Right to Political Participation in International Law' (1992) 17 YJIL 539; James Crawford, 'Democracy and International Law' (1993) 64 BYBIL 113; the contributions in Gregory H Fox and Brad R Roth (eds), Democratic Governance and International Law (CUP 2000) and in Richard Burchill (ed), Democracy and International Law (Ashgate 2006); Steven Wheatley, 'Democracy in International Law: A European Perspective' (2002) 51 ICLQ 225; Jackson N Maogoto, 'Democratic Governance: An Emerging Customary Norm?' (2003) 5 U Notre Dame Aust L Rev 55; Christian Pippan, 'International Law, Domestic Political Orders, and the "Democratic Imperative": Has Democracy Finally Emerged as a Global Entitlement?' (2010) Jean Monnet Working Paper 2/10 <http://www.jeanmonnetprogram.org/ papers/10/100201.html> accessed 31 March 2015; Jean d'Aspremont, 'The Rise and Fall of Democracy Governance in International Law: A Reply to Susan Marks' (2011) 22 EJIL 549; Fabienne Peter, 'The Human Right to Political Participation' (2013) 7(2) J Ethics \& Soc Phil 1.

4 Freedom House, 'Freedom in the World 2015: Discarding Democracy: Return of the Iron Fist', $1<$ https:// freedomhouse.org/sites/default/files/01152015_FIW_2015_final.pdf> accessed 29 March 2015. 
The article proceeds in two main sections. The first section contributes to the ongoing debate about the democratic entitlement by proposing that it is best understood as being composed of four distinguishable, and potentially severable, layers. This is important because the erosion of one or more layers of Franck's construct does not necessarily mean the dissolution of the entire edifice. It also demonstrates that only the two top layers-enforceability and the claim to an emergent international customary normdeveloped under the extraordinary conditions of the immediate post-Cold War era. The remaining two base layers are older, more deeply entrenched in international law, and therefore less susceptible to erosion. Finally, this section outlines the main consequences of the democratic entitlement thesis for international legal and political practice.

The second section proceeds to explore the democratic recession and its potential repercussions for the democratic entitlement. It begins by identifying a number of contemporary dynamics which, taken together, indicate we may indeed be witnessing an incipient global democratic recession. Should current declines persist or deepen, the democratic entitlement is likely to weaken in several respects. First, this section argues that the stall (or worse, reversal) in the forward momentum of democracy inherently erodes the claim to an emergent customary entitlement to democratic governance in international law. Second, it demonstrates that even at the zenith of the democratic boom - in the decade and a half between 1990 and 2005-the claim to an emergent right to democratic governance was contested theoretically and practically, and was therefore always somewhat fragile. Finally, the article warns that recent international practice shows significant evidence of weakening international commitment to the democratic entitlement. Should the current slump persist or accelerate, the article concludes, the top two layers of the democratic entitlement edifice in particular are in genuine danger of being undermined.

\section{The democratic boom and its international legal consequences}

To understand the claim to an emergent enforceable right to democratic governance in international law, and so be able to evaluate its ongoing validity, it is important to recognise the layered nature of the claim, and the potential severability of its different components, or layers. Indeed, the right to democratic governance may be understood as layered in two intertwined but distinct senses-historical and substantive-with the earlier two layers deeply embedded in modern international law, and the latter two emerging only in the relatively recent, and in many respects extraordinary, post-Cold War period.

Franck himself saw the democratic entitlement as the outcome of a historical layering process-a dynamic construction progressively built at formative periods of international legal development. The first layer, dating back to the interwar years, was the principle of self-determination which, according to Franck, entailed 'the right of a people organized in an established territory to determine its collective political destiny 
in a democratic fashion. ${ }^{5}$ Looking at the League of Nations and its successor, the United Nations (UN), Wheatley also observes that the idea of sovereign equality between states 'exactly replicates that of political equality within democratic systems of government' and that the opening words of the UN Charter, 'We the Peoples', may also be read to indicate that popular sovereignty forms one of the core principles of the modern international system in general. ${ }^{6}$

Substantively, at the base layer of the edifice lies the idea that the form of domestic political regimes is not solely a matter of state discretion (an internal affair unchecked by international rules) but that international law has some valid role to play in determining its shape. This notion has become deeply embedded in international legal thought, despite the fact that it represents a departure from international law's traditional strict agnosticism concerning domestic sources and forms of governmental authority. ${ }^{7}$

The second layer, emerging as part and parcel of the anti-totalitarianism impetus of the post-Second World War international settlement, and extending until the collapse of the Soviet Union and the end of the Cold War, involved the beginning of acceptance of the idea that domestic power would be constrained by universal human rights. It entailed more specifically that those rights included a right to political participation, as represented particularly in article 21 of the 1948 Universal Declaration of Human Rights (UDHR). ${ }^{8}$

Franck saw this second layer as also supplemented by certain civil and political rights-freedom of opinion, expression and assembly-necessary for a genuinely open and competitive electoral process, and embodied in various global and regional regimes. ${ }^{9}$ In ideologically divided Europe, for example, the 1949 Statute of the Council of Europe ${ }^{10}$ affirmed democracy as a central goal of the newly formed organisation. In

5 Franck (n 2) 52.

6 Wheatley (n 3) 227.

7 With one or two narrow and fairly recent caveats, international law has traditionally eschewed the subject of domestic governance institutions, procedures or norms, leaving the form and contents of political regimes largely to the discretion of states, as a matter of internal affairs unchecked by international rules. See Case Concerning Military and Paramilitary Activities in and against Nicaragua (Nicaragua $v$ United States of America) (Merits) [1986] ICJ Rep 14, 132. The caveats to this general rule are historically recent and pertain to a prohibition of apartheid (see International Convention on the Suppression and Punishment of the Crime of Apartheid (adopted 30 November 1973, entered into force 18 July 1976) 1015 UNTS 243) and, more ambiguously, Nazi or fascist political regimes (see Maogoto (n 3) 56-57). Indeed, prior to the great democratic boom of 1974-2004, the only broadly applicable restrictions pertaining to domestic governance were to be found in human rights law, notably in conventions relating to political and civil rights. Yet, these prescriptions addressed limitations on how power could be exercised by governments, rather than how those governments were to be formed, constrained or replaced.

8 Universal Declaration of Human Rights, UNGA Res 217 A(III) (10 December 1948) (UDHR). The right to participate in public affairs, including the right to genuine and periodic elections found in art 21 UDHR is reaffirmed in art 25 of the International Covenant on Civil and Political Rights (adopted 16 December 1966, entered into force 23 March 1976) 999 UNTS 171 (ICCPR). However, the latter provision (which, unlike the UDHR, is legally binding) does not condition governmental authority on respect for the will of the people, as art 21(3) UDHR does.

9 Franck (n 2) 61.

10 Statute of the Council of Europe (adopted 5 May 1949, entered into force 3 August 1949) 87 UNTS 103. 
Latin America, although state practice contradicted it sharply until the 1980s, as early as 1948 the Charter of the Organization of American States (OAS) required that member states be constituted 'on the basis of the effective exercise of representative democracy'. ${ }^{11}$

Substantively, it is within this layer that we identify at least the foundations of the principle that under international law it is democracy, and democracy alone, that has become the basis for governmental legitimacy. While it was only with the West's decisive ideological triumph at the end of the Cold War that the idea of democracy as the sole foundation of political legitimacy gained broad (though never universal) international support, the groundwork for this notion was already put in place earlier, both in the decolonisation context and in the more broadly applicable provisions relating to the right of political participation enshrined in the UDHR and the 1966 International Covenant on Civil and Political Rights (ICCPR). ${ }^{12}$

The third layer (and, to Franck's mind, the final one) was the emerging right to democracy, understood as an entitlement to periodic free and fair elections. With a majority of states in the world coming to practise electoral democracy by the early 1990s, Franck concluded that provisions in human rights regimes begin 'to approximate prevailing practice and thus may be said to be stating what is becoming a customary legal norm applicable to all. ${ }^{13}$ Viewed substantively, this third historical phase of development produces two important and distinct principles capping the democratic entitlement edifice.

The penultimate constitutive principle is the notion of its enforceability. This dimension is dependent upon state practice and the broad acceptance of the legitimacy of actions concerning democratic criteria for membership in regional and international organisations-the use of democratic conditionality by international organisations and democratic socialisation within them ${ }^{14}$-international elections monitoring, ${ }^{15}$ and collective responses to coups d'état-the latter extending as far as internationally sanctioned 'pro-democratic' armed interventions. ${ }^{16}$ Finally, and most ambitiously, comes

11 Charter of the Organization of American States (adopted 30 April 1948, entered into force 13 December 1951) 119 UNTS 3, art 5(d).

12 Both instruments are cited in n 8 above. For analysis, see Maogoto (n 3) 60-64; Peter (n 3 ) 1.

13 Franck (n 2) 64.

14 See Leonardo Morlino and Amichai Magen, 'Methods of Influence, Layers of Impact, Cycles of Change: A Framework for Analysis' in Amichai Magen and Leonardo Morlino (eds), International Actors, Democratization, and the Rule of Law: Anchoring Democracy? (Routledge 2009) 31; Stephen J Schnably, 'Constitutionalism and Democratic Government in the Inter-American System' in Gregory H Fox and Brad R Roth (eds), Democratic Governance and International Law (CUP 2000) 155; Jon C Pevehouse, 'Democracy from the Outside-In? International Organizations and Democratization' (2002) 56 IO 515.

15 On the origins and evolution of international elections monitoring, see Roland Rich, 'Bringing Democracy into International Law' (2001) 1(3) J Democ 20; Arturo Santa-Cruz, 'Constitutional Structures, Sovereignty, and the Emergence of Norms: The Case of International Elections Monitoring' (2005) 59 IO 663.

16 On the use of coercive measures in response to coups or attempted ones, see Brad Roth, 'Government Illegitimacy Revisited: "Pro-Democratic" Armed Intervention in the Post-Bipolar World' [1993] Trans L \& Contemp Probls 481; Michael Byers and Simon Chesterman, "You, the People": Pro-democratic Intervention in International Law' in Gregory H Fox and Brad R Roth (eds), Democratic Governance and International Law (CUP 2000) 259. 
the notion that the democratic entitlement has achieved the status of a customary international norm, even if only an emergent rather than a fully established one.

Two main observations are important at this juncture. First, just as the different substantive layers of the right to democratic government emerged at different historical periods, with widely varying international attitudes towards democracy, they are divisible and, in theory at least, severable. The first two layers - the relevance of international law and the notion of democratic legitimacy-could, in theory at least, endure even if the latter two layers-enforceability and the customary status of the democratic entitlement-were to erode partly or completely. Second, it is vital to remember both the relative brevity of the historical period which has given rise to the last two layers of Franck's construct, and to appreciate the exceptional nature of this historical period, the unipolar moment.

Indeed, the demise of Soviet communism and the end of the Cold War generated three extraordinary liberalising dynamics, which combined to elevate the status of democracy in international politics and law as never before. First, the heady exuberance experienced in the West by the triumph of its capitalist-democratic ethos-a mood famously captured in Francis Fukuyama's The End of History essay ${ }^{17}$ in the summer of 1989-resulted in a reinvigorated sense of Wilsonian zeal. This zeal was experienced mainly, but not exclusively, among Americans, ${ }^{18}$ for the reshaping of the world in line with the 'unabashed victory of economic and political liberalism' appeared to be sweeping across many regions of the world at the time. ${ }^{19}$ In a bipolar world, both the United States and Soviet Union generally coveted allies regardless of their liberal credentials and avoided potentially destabilising political and legal experiments in democracy. The end of the Cold War not only opened the possibility of democratic expansion into the former Communist bloc and non-aligned group of states, it also removed a major rationale for tolerating autocratic practices, particularly among already isolated regimes such as apartheid South Africa and Ceaușcescu's Romania. ${ }^{20}$

Second, the international legal order had become more amenable to the idea that in the post-Cold War era there existed a right of democratic governance, because democracy was rapidly becoming not merely a widely shared human aspiration but the dominant form of government around the world. As Samuel Huntington demonstrated in his influential book, the third wave of global democratic expansion began well before the fall of the Berlin Wall-arguably with the April 1974 Portuguese Revolução dos

17 Francis Fukuyama, 'The End of History?' (The National Interest, Summer 1989) <https://ps321.community. uaf.edu/files/2012/10/Fukuyama-End-of-history-article.pdf> accessed 15 December 2015.

18 On the American Wilsonian tradition and history of seeking to promote democracy, see Thomas Smith, America's Mission: The United States and the Worldwide Struggle for Democracy in the Twentieth Century (PUP 1994).

19 Fukuyama (n 17) 1.

20 Amichai Magen and Michael McFaul, 'Introduction: American and European Strategies to Promote Democracy_Shared Values, Common Challenges, Divergent Tools?' in Amichai Magen, Thomas Risse and Michael McFaul (eds), Promoting Democracy and the Rule of Law: American and European Strategies (Palgrave-Macmillan 2009) 4-5. 
Cravos that overthrew one of the longest standing dictatorships in southern Europebut accelerated markedly after the mid-1980s. ${ }^{21}$ Whereas in 1973 only 26.7 per cent of all states then existing (150) constituted electoral democracies, in 1984 the percentage reached 36.1 and, by 1992, 53.2 per cent. This proportional increase occurred despite the growth in the number of states in the world (to 190). The democratic boom continued throughout the 1990s, reaching a zenith at the turn of the millennium, when 62.6 per cent of all states ranked as electoral democracies. ${ }^{22}$

Moreover, unlike the first two waves of democratisation, the third wave was a truly global phenomenon. In fact, it unfolded mainly outside modern democracy's traditional cradles and boundaries in northern Europe, North America, and among several former colonies of the British Empire. From Portugal in 1974, the third wave spread to the rest of the Iberian Peninsula and Greece, then in the 1980s to Latin America, and in the period of 1990-2000 to much of central and eastern Europe and substantial portions of Eurasia, the Asia-Pacific region, and sub-Saharan Africa. ${ }^{23}$ For the first time in human history, democratic governance could be plausibly portrayed as a (near) universal norm, not a highly bounded regional one.

The idea that democratic entitlement ought to be an integral part of the international legal order also received powerful impetus by-and at the same time helped provide legal legitimacy to-stark policy linkages made by prominent liberal internationalists, in government and academia alike, between domestic democracy and a host of desirable international goods; ranging from democratic peace and reduced transaction costs in global trade to better economic development and compliance with human rights and environmental protection standards. ${ }^{24}$

This 'democratic imperative' thesis was enthusiastically endorsed and promoted by the Clinton Administration-one of whose early foreign policy decisions was to replace George Keenan's doctrine of containment with 'Democratic Enlargement' as the new all encapsulating sobriquet for post-Cold War US foreign policy_and later adopted warmly

21 Samuel Huntington, The Third Wave: Democratization in the Late Twentieth Century (U Oklahoma P 1991) 3-5.

22 All figures from Freedom House, 'Freedom in the World: The Annual Survey of Political Rights and Civil Liberties', annual volumes, compiled and cited in Larry Diamond, The Spirit of Democracy: The Struggle to Build Free Societies Around the World (Times Books 2008) app, Table 2.

23 For a detailed account of this process, see Jørgen Møller and Svend-Erik Skaaning, 'The Third Wave: Inside the Numbers' (2013) 24(4) J Democ 97.

24 For classic statements of this sentiment in the early to mid-1990s, see Anne-Marie Burley (now Slaughter), 'Toward an Age of Liberal Nations' (1992) 33 HILJ 393; Fernando R Teson, 'The Kantian Theory of International Law' (1992) 92 Columbia L Rev 53; Anne-Marie Slaughter, 'International Law in a World of Liberal States' (1995) 6 EJIL 503; Andrew Moravcsik, 'Taking Preferences Seriously: A Liberal Theory of International Politics' (1997) 51 IO 513. For later formulations linking democracy to security, economic development and human wellbeing, see, eg, Bruce M Russett and John R O'Neal, Triangulating Peace: Democracy, Interdependence, and International Organizations (Norton 2000); Joe Siegle, Michael Weinstein and Mort Halperin, The Democracy Advantage: How Democracies Promote Prosperity and Peace (Taylor \& Francis 2004); Francis Fukuyama and Michael McFaul, 'Should Democracy Be Promoted or Demoted?' (2008) 31 Washington Q 23. 
by European leaders. ${ }^{25}$ By 1991, the Conference on Security and Cooperation in Europe (CSCE) and the OAS had already endorsed democracy as the only game in town for their member states, paving the ground for Franck's proclamation of an internationally constituted emerging right to democratic governance. ${ }^{26}$ Between the time of Franck's writing and roughly 2005, the democratic entitlement idea amassed policy and scholarly support, particularly in Europe and the Americas. ${ }^{27}$

\section{International legal consequences}

In the period marking the zenith of the global democratic boom-spanning approximately the decade and a half between 1990 and 2005-we can identify several developments which, taken together, amount to a compelling argument in favour of an emergent international customary obligation for states to live up to at least some standard of democratic legitimacy. This is most strongly evident in those regions of the world, Europe and the Americas, which have made membership and various associated privileges in regional organisations contingent upon formal acceptance of, and respect for, democratic principles. Among members of the European Union (EU) and OAS, at least, democratic procedure as the sole legitimate foundation for government has not only become settled practice but acquired the status of opinio juris sive neccessitatis-the accepted notion that the (democratic) practice has become obligatory.

Reflecting a two-decade process of legal development within the EU, post-Lisbon, the Treaty of the European Union (TEU) itself purports to be 'founded on the values of respect for human dignity, freedom, democracy, equality, the rule of law and respect for human rights including the rights of persons belonging to minorities', which are considered 'values [that] are common to the Member States. ${ }^{28}$ A clear risk of a serious breach by a Member State of these values can result in the suspension of the rights deriving from membership in the EU, including voting rights in the Council. ${ }^{29}$ At the same time, articles 9-12 TEU give comprehensive expression to the principle of democracy within the EU legal order. The Court of Justice of the European Union (CJEU) regularly interprets and applies the principle, ${ }^{30}$ and in its external action, too,

25 Amichai Magen, 'The Rise and Stall of Democratic Enlargement' in Federiga Bindi and Irina Angelescu (eds), The Frontiers of Europe: A Transatlantic Problem? (Brookings 2011) 229.

26 On the CSCE (which in 1994 became the Organization for Security and Cooperation in Europe, OSCE) see the Charter of Paris for a New Europe (adopted 21 November 1990, entered into force 21 November 1990) (1991) 30 ILM 190. On the OAS, see the Santiago Commitment to Democracy and the Renewal of the Inter-American System, 21st Session of the OAS General Assembly (4 June 1991) OAS/Ser.P/AG Doc 2734/91; OAS General Assembly Resolution 1080 (5 June 1991) OAS/Ser.P/AG Doc 2739/91.

27 See Magen and McFaul (n 20) 2-5.

28 Consolidated Version of the Treaty on European Union [2012] OJ C326/15 (TEU) art 2 (emphasis added).

29 Art 7 TEU.

30 See Koen Lenaerts, 'The Principle of Democracy in the Case Law of the European Court of Justice' (2013) 62 ICLQ 271. 
the EU is formally committed to being 'guided by the principles which have inspired its own creation, development and enlargement, and which it seeks to advance in the wider world: democracy, the rule of law, the universality and indivisibility of human rights and fundamental freedoms. ${ }^{31}$

In Europe beyond the EU, the Council of Europe's European Court of Human Rights has ruled that democracy 'appears to be the only political model contemplated by the [European Convention on Human Rights] and, accordingly, the only one compatible with it. ${ }^{32}$ The member states of the Organization for Security and Cooperation in Europe (OSCE) have pledged to 'build, consolidate and strengthen democracy as the only system of government of our nations' as well as to 'cooperate and support each other with the aim of making democratic gains irreversible. ${ }^{33}$ In practice, by the end of the 1990s, monitoring elections, providing financial and technical assistance aimed at strengthening democracy, and judging the extent to which member states were pursuing democratic development had become a central objective for the OSCE. ${ }^{34}$

A similar process, whereby regional organisations institutionalised provisions intended to promote and anchor democratic gains, occurred over the same period in the Americas. Building on its Cold War pro-democracy foundations, in its 1991 Santiago Declaration the OAS committed itself to ensuring the promotion and defence of representative democracy. ${ }^{35}$ By 2001, article 1 of the Inter-American Democratic Charter stated plainly, 'The peoples of the Americas have a right to democracy and their governments have an obligation to promote and defend it. ${ }^{36}$ Beyond declarations, in 1990 the OAS established a Department of Electoral Cooperation and Observation, with a specialised electoral quality and certification office operating since 2007 under the auspices of the regional organisation.

Another indicator of normative commitment to democracy pertains to the reaction of the international community to the usurpation of governmental power by extraconstitutional means, typically coups deetat. In the 1990-2005 period, we observe broad international objections to such action, sometimes backed by substantial sanctions. ${ }^{37}$ For instance, under Resolution 1080 adopted by the OAS General Assembly in 1991, in the event of 'any occurrences giving rise to the sudden or irregular interruption of the democratic political institutional process or of the legitimate exercise of power by a democratically elected government,' OAS member states are collectively empowered

31 Art 21 TEU (emphasis added).

32 United Communist Party of Turkey and others $v$ Turkey (1998) 26 EHRR 121, para 45. The instrument referred to is European Convention for the Protection of Human Rights and Fundamental Freedoms (adopted 4 November 1950, entered into force 3 September 1953) ETS No 5.

33 Charter of Paris for a New Europe, 4.

34 Rich (n 15) 28.

35 OAS Santiago Commitment to Democracy.

36 OAS, Inter-American Democratic Charter (adopted 11 September 2001) (2001) 40 ILM 1289, art 1.

37 See Jean d'Aspremont, 'Responsibility for Coups in International Law' (2010) 18 Tulane J Intl \& Comp L 451. Note, however, that such sanctions have typically been eased once the perpetrators of the coups make a credible promise to hold free and fair elections. 
to 'adopt any decisions deemed appropriate, in accordance with the [OAS] charter and international law. ${ }^{38}$ By 2005, Resolution 1080 was invoked five times-in Haiti (1991), Peru (1992 and 2000) Guatemala (1993) and Paraguay (1996). ${ }^{39}$ The existence of collective mechanisms for protecting democracy-which also exist, albeit less robustly, in the Commonwealth of Nations ${ }^{40}$ and African Union ${ }^{41}$-lend credence to the notion of the international community is at least resisting authoritarian backsliding and seeking to lock in existing democratic gains. ${ }^{42}$

Most remarkable, and controversial, has been the appeal to collective military intervention to enforce the ostensible right to democratic governance. ${ }^{43}$ While stopping well short of Michael Reisman's call for the development of a general customary right to unilateral armed intervention as a measure of last resort in cases of violation of democracy, ${ }^{44}$ the post-Cold War period has in fact produced a limited doctrine of coercive intervention, under Chapter VII of the UN Charter, in support of the democratic entitlement. As Roland Rich observes, in at least three cases over the 1990-2005 periodin Haiti (1994), Sierra Leone (1997) and East Timor (1999) — a credible argument can be made that the Security Council authorised coercive enforcement action on human rights and democracy grounds even where there was very little danger to international peace and security. ${ }^{45}$

Finally here, the right to democratic governance as an emergent customary international norm was buttressed to some extent between 1990 and 2005 by international practice pointing to democratic legitimacy as a factor affecting the recognition of new states. Traditionally, state recognition did not address questions of domestic regime structure, and even today there is certainly no evidence to indicate that states refuse to recognise the existence of another state simply because it possesses a non-democratic form of government. ${ }^{46}$ A notably pro-democracy development in recognition practice did take place in the immediate aftermath of the Cold War, however, when both the United States and EU declared that, with respect to the dissolution of the Soviet Union and Yugoslavia,

38 OAS General Assembly Resolution 1080, art 2. For commentary and analysis of these cases, see Ruben M Perina, 'The Role of the OAS' in Morton Halperin and Mirna Galic (eds), Protecting Democracy: International Responses (Lexington 2005) 127.

39 Perina (n 37) 127.

40 Charter of the Commonwealth of Nations (adopted 14 December 2012) art $1<\mathrm{http}: / /$ thecommonwealth. $\mathrm{org} / \mathrm{sites} /$ default/files/page/documents/CharteroftheCommonwealth.pdf $>$ accessed 2 October 2015.

41 Constitutive Act of the African Union (adopted 11 July 2000, entered into force 26 May 2001) OAU Doc CAB/LEG/23.15, arts 3(g), 4(m).

42 See Theodore J Piccone, 'International Mechanisms for Protecting Democracy' in Morton Halperin and Mirna Galic (eds), Protecting Democracy: International Responses (Lexington 2005) 101; Niels Peterson, 'The Principle of Democratic Teleology in International Law' (2008) Max Planck Institute for Research on Collective Goods 16/2008 <http://core.ac.uk/download/pdf/7372250.pdf> accessed 15 April 2015.

43 See the debate about the legality of coercive intervention in support of democracy in part III of Gregory $\mathrm{H}$ Fox and Brad R Roth (eds), Democratic Governance and International Law (CUP 2000).

44 W Michael Reisman, 'Humanitarian Intervention and Fledgling Democracies' (1994) 18 FILJ 794.

45 Rich (n 15) 31.

46 Sean Murphy, 'Democratic Legitimacy and the Recognition of States and Governments' (1999) 48 ICLQ $545,556$. 
recognition would require not only the fulfillment of the traditional Montevideo criteria, but adherence to democracy. ${ }^{47}$ Similarly, the international trusteeships established to shepherd Bosnia-Herzegovina, East Timor, and Kosovo towards full statehood all required that the transitional entities become democratic states. ${ }^{48}$

In sum, over the period 1990-2005 we observe a structural shift in the status of democracy, as an ideal and model of government, in the international system. Writing in 2004, leading democratisation scholar Laurence Whitehead captured this sense of democratic triumphalism and necessity, observing that:

Democratization is now more commonly viewed as the norm rather than the exception. Unsatisfactory outcomes are most often presented as temporary setbacks to a predetermined course. There has been an explosion of international political and economic incentives for states to qualify as democracies. Where such expectations are clearly being frustrated, the leaders of international opinion reach for such labels as 'rogue states', 'collapsed' or 'failed' states, often as a pretext for encroachments on state sovereignty. There has been a proliferation of the use of coercion and intervention in the name of human rights and democracy, and transitional administrations that are supposed to help instill new democratic regimes. This radical shift in the outlook of international actors reflects the end of the bi-polar conflict and the discredit of socialist economic models. More recently it has been reinforced by a perception that Western-led security interests are best served by managing the risks of controlled democratization. ${ }^{49}$

It is during this latter period of 'the third wave' that a credible (though, as we shall see, not overwhelming) argument can be made for the emergence of the democratic entitlement as an enforceable customary norm, extending beyond democracy's traditional cradle in western Europe, North America and a handful of former colonies of the British Empire.

\section{The democratic recession and what it may mean for international law}

Gains in political freedom worldwide reached a high water mark around 1999-2000, stagnated between the turn of the millennium and 2005-06, and then entered a process of decline after 2006. Since 2006, there has been no net expansion in the number of electoral democracies-which has wavered between 114 and 119, or between 60 and 63

47 See 'Guidelines on the Recognition of New States in Eastern Europe and in the Soviet Union' (1991) 62 BYBIL 559; 'Declaration on Yugoslavia' (1991) 62 BYBIL 559. For commentary, see the same volume at 558-66.

48 See Oisin Tansey, Regime-Building: Democratization and International Administration (OUP 2009) 61-204. On the democratic dilemmas of building democratic states through 'benevolent autocracy', see Simon Chesterman, You, The People: The United Nations, Transitional Administration, and State-Building (OUP 2004) 126-52.

49 Laurence Whitehead, 'Democratization with the Benefit of Hindsight: The Changing International Components' in Edward Newman and Roland Rich (eds), The UN Role in Promoting Democracy: Between Ideals and Reality (UNUP 2004) 135-36. 
per cent of the world's states-and the number of both electoral and liberal democracies has dropped slightly. ${ }^{50}$ The average level of freedom in the world, as measured by the Freedom House index, also worsened somewhat over this period, from a best score of 3.22 in 2005 to 3.30 in $2013-14 .^{51}$

While it is still unclear whether we are witnessing a stock market-like temporary correction in an otherwise upward historical trend, or the advent of a genuine 'reverse wave' characterised by democratic breakdowns and authoritarian resurgence, the combined impact of several dynamics now give substantial cause for concern of an accelerating global democratic recession.

Beyond the halting of the 1974-2004 positive momentum and the erosion in the number of democracies, the world has experienced a growing rate of democratic breakdowns in the last decade and a half. Between 2000 and 2015, 17.6 per cent of democracies in the world broke down-as a result of coups, rigged elections or other incremental degradations of democratic procedures-compared to lower democratic failure rates of only 8 per cent in the period 1984-93 and 11 per cent in 1994-2003. ${ }^{52}$ Many of these have taken place in large, strategically important states, including Pakistan (1999) - which prominent analysts saw as a harbinger of future decline $e^{53}$-Russia (2000), Nigeria (2003), Venezuela (2005), Thailand (2005 and 2014), the Philippines (2007), Kenya (2007), Ukraine (2012), and Turkey (2014).

In addition to outright democratic breakdowns, we also observe accelerating declines in scores of freedom in a number of regions of the world post-2006. After a decade of nearly uninterrupted gains in freedom outpacing losses by a ratio of at least two to one, the trend was broken in 2006, and since then more countries have consistently declined in freedom than improved. By 2014, Freedom House notes that:

nearly twice as many countries suffered declines as registered gains, 61 to 33, with the number of gains hitting its lowest point since the nine-year erosion began. This pattern held true across geographical regions. ${ }^{54}$

The erosion is compounded by the fact that a troubling number of backsliding states are either large, economically powerful, or regionally influential ones-including Russia, Venezuela, Egypt, Turkey, Thailand, Nigeria, Kenya, Azerbaijan-or are members of the EU, especially Hungary and Romania. ${ }^{55}$

50 Larry Diamond, 'Facing Up to the Democratic Recession' (2015) 26(1) J Democ 141, 142.

51 ibid. The Freedom House index assigns each country and territory two numerical ratings-one for political rights and one for civil liberties-based on a 1-7 scale, with 1 being the best and 7 the worst. A larger average score demonstrates a global deterioration in the level of political rights and civil liberties tracked by the index.

52 Diamond (n 50) 144.

53 See, eg, Larry Diamond, 'Is Pakistan the (Reverse) Wave of the Future?' (2000) 11(3) J Democ 91.

54 Freedom House (n 4) 1.

55 On the deteriorating conditions of democracy inside the EU, see Attila Agh, 'Decline of Democracy in East-Central Europe: The Last Decade as the Lost Decade in Democratization' (2014) 7(2) J Comp Pol 4; 
Just as disturbing as the statistical declines is an increasingly assertive authoritarian resurgence. This has taken a number of forms. At the height of the democratic boom, nearly all dictatorships either sought to persuade international public opinion that their regimes were democratic (as in the case of Vladimir Putin's 2005 claim that Russia constituted a 'managed democracy') ${ }^{56}$ or that they are gradually moving towards democracy (China, Egypt, Jordan, Kuwait, Saudi Arabia). Now, autocrats feel freer to flout democratic values openly, assert the superiority of non-democratic forms of government, and violate the core principles of the liberal international order. This trend has been most pronounced in Russia-which has sharply restricted space for political dissent, treats human rights activists as enemies of the state, and directly violated international agreements guaranteeing Ukraine's territorial integrity-and China, which has abandoned 'softer' methods of authoritarian control, and has resorted to cruder Cold War-era tools, including criminal sanctions designed to restrict civil activists, administrative detention, and even the placement of dissidents in psychiatric hospitals. ${ }^{57}$

At the same time, Russia, China and regional powers such as Iran and Venezuela increasingly seek to wield economic, diplomatic and 'soft power' instruments in an attempt to discredit Western democracies and promote their own models as legitimate alternatives for other countries to emulate. ${ }^{58}$ As part and parcel of the new assertiveness, authoritarian and semi-authoritarian regimes are leading a growing, and increasingly coordinated, assault on Western democracy promotion efforts; imposing various constraints on NGOs, closing down pro-democracy organisations, and harassing activists. $^{59}$

Another facet of the democratic recession can be observed in the general dashing of the Arab Spring hopes for political liberalisation in north Africa and the Middle East, the cascade of state failure in the region (most notably in Iraq, Libya, Syria and Yemen), and the rising influence of revolutionary Shi'a and radical Sunni movements from Marrakesh to Bangladesh. Indeed, in the post-Arab Spring resurgence of radical Islamist ideologies and groups we observe not only the return of religion as an alternative organisational principle of world politics, but the outright rejection of all forms of man-made law, democracy, and the Westphalian international order. ${ }^{60}$ Salafist jihadi movements in

Ulrich Sedelmeier, 'Anchoring Democracy from above? The European Union and Democratic Backsliding in Hungary and Romania' (2014) 51 JCMS 105.

56 Vladimir Putin, 'Annual Address to the Federal Assembly of the Russian Federation' (The Kremlin, Moscow, 25 April 2005) <http://archive.kremlin.ru/eng/speeches/2005/04/25/2031_type70029type82912_87086. shtml $>$ accessed 14 December 2015.

57 Agh (n 55) 3-5. The Freedom House 2015 Report (n 4) also identifies similar trends in Turkey, Venezuela, Azerbaijan, Ethiopia, Vietnam, and Saudi Arabia.

58 See Andrew Nathan, 'China's Challenge' (2015) 26(1) J Democ 156.

59 See Thomas Carothers, 'The Continuing Backlash against Democracy Promotion' in Peter Burnell and Richard Youngs (eds), New Challenges to Democratization (Routledge 2010) 59.

60 See Barak Mendelsohn, 'God vs Westphalia: Radical Islamic Movements and the Battle for Organizing the World' (2012) 38 Rev Int Stud 589; Daveed Gartenstein-Ross and Tara Vassefi, 'Perceptions of the "Arab Spring” within the Salafi-Jihadi Movement' (2012) 35 Studies in Conflict \& Terrorism 831. 
particular (notably Al Qaeda, its regional affiliates, and ISIS) are increasingly contesting the most fundamental values and institutions of modern political liberalism.

Perhaps the most serious contemporary challenges to the democratic entitlement idea, however, emanate from within the democratic world itself. Here we can identify three main causes of growing democratic fragility.

First, within the most powerful democracies-in North America and Europedemocratic performance has been conspicuously deficient. The United States and the EU, arguably the two geographical epicentres of the liberal international order (and the main drivers of the democratic entitlement idea), have experienced a profound financial crisis in the late 2000s, appear mired in political paralysis (where their respective democratic institutions seem unable to answer citizen expectations and deliver effective governance), and face a series of daunting, long term, structural socioeconomic challenges. These challenges range from slow growth and stagnating income, to ageing populations and looming entitlements crises, and (in the case of European states) demographic decline. At the same time, voter turnout, levels of political party membership and public trust in government are all declining in America and Europe. ${ }^{61}$

Second, as has been evident throughout recorded human history, and as Robert Kagan aptly puts it, 'Politics follows geopolitics. ${ }^{\text {' }}{ }^{\text {Just }}$ as the rise of Athenian democracy in the fifth century BCE prompted the spread of democratic ideas and models of government among the Greek city states, Sparta's eventual victory in the Peloponnesian War was reflected in the proliferation of oligarchic rule. When the Soviet Union's power increased in the early years of the Cold War, the number of communist regimes in the world rose; when it disintegrated, countries flocked to emulate the peerless American hegemon, including its triumphant model of government. It should come as no surprise, therefore, that the (at least relative) decline in Western power, self-confidence, and energy is producing a downturn in the appeal of democracy, if not yet an outright drift towards its enemies.

Lastly, democratic fragility is increasingly pervasive, especially among newer liberal democracies, as well as the weaker, more illiberal ones, because of their apparent inability to fulfill citizen expectations of effective public services provision. ${ }^{63}$ Conversely, the fact that authoritarian regimes, such as China and Singapore in Asia and, to a lesser extent, Venezuela in Latin America, have been able to deliver seemingly effective governance raises their prestige relative to democracy. ${ }^{64}$

61 For a detailed discussion of democratic decay within the West, see in particular Francis Fukuyama, Political Order and Political Decay: From the Industrial Revolution to the Globalization of Democracy (Farrar, Straus and Giroux 2014) 455-548; Philip Coggan, The Last Vote: Threats to Western Democracy (Penguin 2013); 'What's gone Wrong with Democracy and how to Revive it', The Economist (London, 1-7 March 2014 ) 43.

62 Robert Kagan, 'The Weight of Geopolitics' (2015) 26(1) J Democ 21.

63 See Francis Fukuyama, 'Why is Democracy Performing so Poorly?' (2015) 26(1) J Democ 11; Emmanuel Gyimah-Boadi, 'Africa's Waning Democratic Commitment' (2015) 26(1) J Democ 101; Scott Mainwaring and Anibal Perez-Linan, 'Cross-Current in Latin America' (2015) 26(1) J Democ 114; Alina MungiuPippidi, 'The Splintering of Postcommunist Europe' (2015) 26(1) J Democ 88.

64 See Nathan (n 58); Kagan (n 62). 
Well performing modern democracies, as Fukuyama shows, combine three core functions: the state, the rule of law, and democratic accountability. ${ }^{65}$ In many new democracies, state capacity and the rule of law have lagged well behind the progress in democratic accountability achieved by the spread of electoral democracy over the past decades; creating growing popular disillusionment with (and ultimately the delegitimation of) democracy in many societies. ${ }^{66}$ State capacity and rule of law gaps exist to some extent even within the democratic heartland of the $\mathrm{EU}^{67}$ but are most prevalent in those regions of the world that have made democracy a truly international, not merely regional, norm-in Africa, Latin America, and the former Soviet bloc. ${ }^{68}$

\section{What implications for the right to democratic governance?}

How will the post-2006 decline in the fortunes of democracy impact the emergent right to democratic governance in international law? The answer to this question will ultimately hinge on how democracy will fare in the international system, at the regional and global levels, in the coming years and decades. Should the current slump prove to be a short term correction in an otherwise robust, historical 'freedom's march', one can expect the gradual, long term consolidation and deepening of the democratic entitlement, quite possibly to the point of becoming a universal, enforceable rule. ${ }^{69}$

In contrast, should post-2006 declines endure and deepen, the democratic entitlement will weaken and erode, though it is highly unlikely to be obliterated. The remainder of this section identifies the factors that are likely to contribute to the erosion of the right to democratic governance, should the contemporary democratic recession persist or accelerate. At the same time, it advances the argument that, given the layered nature of the democratic entitlement idea, the right to democratic governance is unlikely to be entirely undone even in the face of deep reversals.

One set of factors that endanger the future of the democratic entitlement idea pertain to the fragility of the concept itself. The claim to an emergent right to democratic governance in the post-Cold War era depends in some vague but fundamental way on the forward momentum of democracy as an ideal and model of government in the world. Where that momentum is stalled, let alone reversed, the emergent right is no

65 Francis Fukuyama, The Origins of Political Order: From Prehuman Times to the French Revolution (Farrar, Straus and Giroux 2011) 14-16.

66 Fukuyama, 'Why is Democracy Performing So Poorly?' (n 63).

67 See Agh (n 54); Sedelmeier (n 54).

68 See Freedom House (n 4); Gyimah-Boadi (n 63); Mainwaring and Perez-Linan (n 63); Mungiu-Pippidi (n 63).

69 Some policy makers and scholars have suggested mechanisms for moving in this direction. See, eg, John McCain, 'An Enduring Peace Built on Freedom' Foreign Affairs (November-December 2007) <https:// www.foreignaffairs.com/articles/2007-11-01/enduring-peace-built-freedom> accessed 15 December 2015; Piccone (n 39) 122-23. 
longer emergent and the validity of the notion is inherently undermined, though it is still unclear to what extent it suffers and with what exact consequences.

Even at the height of the global democratic boom, moreover, the democratic entitlement notion was always a contested one, both theoretically and as evidenced by the state practice of non-democracies.

In the realm of theory, Franck's thesis has attracted varied and substantial challenges for its alleged conceptual shortcomings and undesirable policy implications. Susan Marks, for instance, faults the democratic entitlement idea, as formulated by American scholars in particular, for being both too shallow and narrow. Franck's emphasis on the electoral, procedural dimensions of democracy, she argues, means that his conception is a minimalist and superficial one-what she calls 'low-intensity democracy'-that privileges elite political competition at the expense of genuine democratic inclusion and empowerment. ${ }^{70}$ Echoing David Held's work, Marks further charges that the democratic entitlement's 'pan-national' focus is too narrow, in that it addresses municipal-level democracy alone and neglects the need for democratic accountability in those decisionmaking realms that are transnational or supranational in nature. ${ }^{71}$

Christian Pippan similarly observes that, even at its apex, the ambit of the principle of democracy in international law was highly limited, extending only to the thin, electoral or procedural understanding of democracy. In other words, Pippan contends, a democratic entitlement can only be said to have emerged if democracy is equated with periodic free elections alone. ${ }^{72}$ As such, the right to democratic governance, as presently formulated, can be seen to neglect all non-electoral dimensions of democracy-to use Fukuyama's terms, the statehood and rule of law functions-and so is tainted by the growing disillusionment with the poor performance of many contemporary democracies.

Other critics have rejected the right to democratic governance on policy grounds, castigating it as a pernicious instrument designed to erode long-established norms of Westphalian sovereignty, non-intervention, and the general prohibition of aggression. Brad Roth, for instance, has sharply attacked Franck's 'democratic legal rhetoric', calling it 'an inherently mischievous device to legitimate the interference of hegemonic external forces in local democratization processes. ${ }^{73}$ While Roth's attack might be dismissed as extreme and unwarranted-both for its uncorroborated presumption of malice and for ignoring the many facets of external influence on domestic political change-its sheer acerbity serves to emphasise the contested nature of Franck's claim.

70 Susan Marks, The Riddle of All Constitutions: International Law, Democracy, and the Critique of Ideology (OUP 2000) 50-75.

71 ibid 76-100. In this latter critique Marks echoes David Held's call to expand the democratic ethos to political life beyond national state systems to all arenas of authority exercising major influence on people's lives. See David Held, Democracy and the Global Order: From the Modern State to Democratic Governance (Stanford UP 1995).

72 Pippan (n 3) 32-33.

73 Brad R Roth, 'Book review: The Riddle of all Constitutions: International Law, Democracy, and the Critique of Ideology by Susan Marks' (2001) 77 Intl Affairs 411, 412. 
More importantly perhaps, inconsistent state practice has always ensured that the claim to an enforceable customary norm has been fragile. The proportion of democracies in the world never exceeded 62.6 per cent, with three major regions-Asia, sub-Saharan Africa, and north Africa and the Middle East-never achieving even a bare majority of electoral democracies, and authoritarian colossi (including China and virtually all Arab countries) persisting throughout the global democratic boom. ${ }^{74}$ In this context, Jean d'Aspremont is surely correct in asserting that any customary obligation that exists in relation to a democratic entitlement probably constitutes an erga omnes obligation but is certainly not of a jus cogens character given the continuous existence of substantial persistent objectors to the principle in the international system. ${ }^{75}$ Should democratic reversals and resurgent authoritarianism deepen or accelerate, particularly in Europe, but also in those regions of the world that presently appear most vulnerable to declineAfrica, Asia, those parts of the former Soviet bloc not integrated into the EU and NATO, and Latin America-it is difficult to see how the notion of a customary right - that is, the top layer of the democratic entitlement idea-can resist erosion.

Similarly, maintaining the existence of a customary obligation upon states to live up to some democratic standard would become more difficult if anti-democratic ideological movements acquire more adherents in Central Asia, Africa and the Middle East, if the open flouting of democratic norms become more widespread, or if authoritarian action to undermine pro-democracy international instruments and programmes become more brazen and systematic.

In reality, over the past few years there are indications of weakening state practice regarding the efficacy of democratic credentials or protection of democratic standards. Given the newness of the trend, firm conclusions are impossible to draw, however the trend is manifested in several tangible ways.

Most seriously perhaps, unlawful seizures of power, while still likely to produce some diplomatic opprobrium, no longer appear to prompt non-recognition of the new government or some other serious sanction. For example, following the 2006 military coup in Thailand, the United States condemned the generals responsible and suspended US\$24 million in military aid to the country. ${ }^{76}$ By the time of the second Thai coup, which deposed Prime Minister Yingluck Shinawatra in May 2014, however, the Obama administration temporarily held back some US $\$ 4.7$ million in military aid and halted a small officer exchange programme, ${ }^{77}$ yet there is no evidence to suggest the United States

74 Møller and Skaaning (n 23).

75 d’Aspremont, 'A Reply to Susan Marks' (n 3) 557.

76 Thomas Lum, 'US Foreign Aid to East and South Asia: Selected Recipients' (Congressional Research Service Report for Congress, 3 January 2007) <http://fpc.state.gov/documents/organization/81357.pdf> acessed 13 August 2015. The suspension included military aid and counter-terrorism assistance. Assistance was restored in February 2008, only after elections judged to be free and fair where conducted in Thailand.

77 Emma Chanlett-Avery, Ben Dolven, and Wil Mackey, 'Thailand: Background and US Relations' (Congressional Research Service Report for Congress, 29 July 2015) <https://www.fas.org/sgp/crs/row/ RL32593.pdf $>$ accessed 13 August 2015. 
considered non-recognition of the usurper government. In fact, the United States quickly joined Thailand in two military exercises after the coup, ${ }^{78}$ signaling that regional security competition with China trumped any American concern over the second military coup in Thailand in seven years.

Similarly, in Egypt, the Obama administration stopped short of defining Abdel Fattah el-Sisi's July 2013 toppling of the country's elected government a military coup, though it clearly was, ${ }^{79}$ since doing so would have automatically triggered the suspension of military assistance to Egypt under the United States Foreign Operations Appropriations Act. ${ }^{80}$ Although condemned rhetorically, the 2013 Egyptian coup carried only minor and temporary unease for Egypt's new strongman. By June 2014, US\$575 million in American aid that had previously been held back was released ${ }^{81}$ and, in March 2015, a further US $\$ 700$ million was promised..$^{82}$ In August 2015, US Secretary of State, John Kerry, visited Cairo for a strategic dialogue, and western leaders, including French President, François Hollande, attended the opening ceremony of the new Suez Canal. ${ }^{83}$

More importantly still, in terms of state practice and opinio juris, is the fact that, in January 2014, Congress passed legislation exempting Egypt (and Egypt alone) from the clause in the Appropriations Act which prohibits military aid to countries that have undergone a military coup prior to the restoration of a democratic government by means of free and fair elections. ${ }^{84}$

Another apparent withdrawal from earlier state practice is observable in the area of recognition of new states and the criteria for the transition of political entities into full statehood. Two recent cases are illustrative in this regard. After 2010, international deliberations concerning South Sudan's impeding independence and recognition as

78 Craig Whitlock, 'US Military to Participate in Major Exercise in Thailand Despite Coup' The Washington Post (Washington, 8 February 2015).

79 Tarek Masoud, 'Has the Door Closed on Arab Democracy?' (2015) 26(1) J Democ 74, 76.

80 Foreign Operations Appropriations Act $\$ 508$, which provides that such funds shall not be made available to any country whose duly elected head of government was deposed by a military coup. Under $\$ 508$, the funds can be reinstated once a democratically-elected government is in place. See Lum (n 76) 25. For analysis of the dilemma facing US State Department lawyers in the case of the 2013 Egyptian military coup, see Elizabeth Imbarlina, 'Reforming the FAA Section 508' (Jurist, 29 July 2013) <http://jurist.org/ dateline/2013/07/steven-aiello-legislation-reform.php> accessed 13 August 2015.

81 'US Unlocks Military Aid to Egypt, Backing President Sisi' BBC News (24 June 2014) <http://www.bbc. com/news/world-middle-east-27961933> accessed 13 August 2015.

82 Peter Baker, 'Obama Removes Weapons Freeze Against Egypt' New York Times (31 March 2015) <http:// www.nytimes.com/2015/04/01/world/middleeast/obama-lifts-arms-freeze-against-egypt.html?_r=0> accessed 13 August 2015.

83 Eric Knecht, 'Egypt's Sisi Opens New Suze Canal, Says to Defeat Terrorists' Reuters (6 August 2015) <http://uk.reuters.com/article/2015/08/06/uk-egypt-suezcanal-idUKKCN0QB1JW20150806> accessed 13 August 2015.

84 See Amy Hawthorne, 'What's Happening with US Military Aid to Egypt, Part II: Everything you Ever Wanted to Know about Foreign Military Financing for Egypt' (Atlantic Council, 17 November 2014) <http://www.atlanticcouncil.org/blogs/egyptsource/what-s-happening-with-us-military-aid-to-egypt-partii-everything-you-ever-wanted-to-know-about-the-2014-legislation-on-foreign-military-financing-foregypt> accessed 13 August 2015. The statute in question is Consolidated Appropriations Act 2014 (US). 
the 193rd member state of the UN contain remarkably little attention to domestic governance arrangements, and virtually no indication that democratic legitimacy would constitute a factor in its recognition. Security Council Resolution 1996 (2011) recognises the establishment of South Sudan as an independent state and establishes a UN mission in the new state's capital, Juba. However, in the eight-page document, democracy is mentioned only once and then in reference to the mandate of the new UN mission (UNMISS), not the expected domestic government arrangement of the newly formed state. ${ }^{85}$ Similarly, UNSC Resolution 1999 (2011), which grants South Sudan full membership in the UN, speaks of the need for the new state to work closely with the UN to ensure, inter alia, 'establishment of core governmental functions, provisions of basic services, establishment of the rule of law, respect for human rights [and] management of natural resources, ${ }^{86}$ but makes no mention of free and fair elections or any other reference to democracy per se.

This retreat from the democratic principle lends support to d'Aspremont's observation in 2011 that we may be witnessing a weakening, in the international community, of care for the origin of government-whether it is democratic or not-in favour of growing attention to what he and de Brabandere call the 'legitimacy of exercise' of power-that is, whether political power is exercised in an effective manner, ensuring security, the rule of law, and provision of other public goods, with less attention paid to electoral competition or other democratic procedures. ${ }^{87}$

The trend of de-emphasising democratic credentials in recent years is also apparent in the case of the Palestinian quest for recognition of full statehood status and membership in the UN. A comparative examination of the formal statements of the Middle East Quartet (composed of the US, the EU, Russia and the UN) demonstrates the gradual decline of attention to democracy. In 2002-03, the Quartet made three formal statementsmost notably in its April 2003 performance-based roadmap to a permanent two-state solution to the Israeli-Palestinian conflict-on the conditions for peace between Israelis and Palestinians and a vision of a two-state solution, with a democratic Palestinian state living securely alongside democratic Israel. ${ }^{88}$ All three statements mentioned democracy explicitly. Similarly, in 2004, the Quartet made two statements, both of which stated that a future Palestinian state must be democratic. The trend continued until 2010 but has since stopped. Since September 2010, the Quartet has made 11 formal statements about a future Palestinian state, but none have mentioned democracy. ${ }^{89}$

85 UNSC Res 1996 (8 July 2011) UN Doc S/RES/1996.

86 UNSC Res 1999 (13 July 2011) UN Doc S/RES/1999.

87 d'Aspremont, 'A Reply to Susan Marks' (n 3) 560-61; Jean d'Aspremont and Eric de Brabandere, 'The Complementary Faces of Legitimacy in International Law: The Legitimacy of Origin and the Legitimacy of Exercise' (2011) 34 FILR 190.

88 See US Department of State, 'A Performance-Based Roadmap to a Permanent Two-State Solution to the Israeli-Palestinian Conflict' (30 April 2003) <http://2001-2009.state.gov/r/pa/prs/ps/2003/20062.htm> accessed 13 August 2015.

89 See UN News Centre, Middle East Quartet Statements <http://www.un.org/apps/news/docs. asp?Topic=Middle\%20East\&Type=Quartet\%20statement $>$ accessed 13 August 2015. 


\section{Conclusions}

Though the brevity of the period of time we are examining makes the drawing of any decisive observations about international trends with significant legal consequences difficult, current state practice demonstrates a loosening commitment to democracy, notably in comparison to the immediate post-Cold War period. Anti-liberal states and movements increasingly challenge regional and global mechanisms based on democratic conditionality and socialisation, and Western actors appear less determined to press for such mechanisms, preferring perhaps to emphasise security, energy and other 'hard interests' while de-emphasising democratic legitimacy as a factor in international cooperation. Commitment to democratic institutions and norms appear to be playing a lesser role in contemporary practice pertaining to the formation of new states and recognition of new states, and even outright military coups do not always lead to significant sanctioning.

Taken together, the incipient democratic recession and current indications of weakening international commitment to democracy do not fundamentally endanger the first base layers of the democratic entitlement, but they do place in jeopardy the top two layers achieved only in the aftermath of the Cold War. The customary nature of the claim, and the notion that it has become enforceable, stand to be seriously eroded if the current democratic slump-including Western policies demonstrating an acceptance of a weakened international commitment to democracy-is permitted to persist or, worse, accelerate.

Preserving the democratic entitlement idea requires democracy's champions to deepen their resolve to safeguarding existing gains and, at the same time, to develop, inter alia, new democracy-supporting international instruments. One future direction would promote the development of a new species of democratic governance treaties, as a means of overcoming the legitimate critique that the right to democratic governance, as conceived of to date, is shallow and narrow to the point of being self-defeating. Moreover, the development of a new wave of regional, perhaps even global, democratic governance treaties would seek to bolster the protection, anchoring, and promotion of political rights within domestic systems. As the author has written elsewhere, the rule of law is an area that can lead the development of a new species of democratic governance treaties, given the broad international legitimacy now accorded to the idea and ideal of the rule of law. ${ }^{90}$

90 See Amichai Magen, 'The Rule of Law and its Promotion Abroad: Three Problems of Scope' (2009) 45 Stanford J Intl L 51. 